\title{
Statistical Comparison of Reference Evapotranspiration Methods: A Case Study from Srinagar in J\&K, India
}

\author{
Shakeel Ahmad Bhat ${ }^{1 *}$, Bashir Pandit ${ }^{1}$, Mehraj U. Din Dar ${ }^{2}$, Rehana Jan ${ }^{3}$, \\ Shafat Khan ${ }^{4}$ and Khanday Mehraj ${ }^{3}$ \\ ${ }^{1}$ Division of Agricultural Engineering, Skuast Kashmir, India \\ ${ }^{2}$ Punjab Agricultural University, Punjab, India \\ ${ }^{3}$ Division of soil science SKUAST-K, J \& K, India \\ ${ }^{4}$ Indian Institute of Technology, Kharagpur, West Bengal, India \\ *Corresponding author
}

\section{A B S T R A C T}

\begin{tabular}{|l|}
\hline K e y w o r d s \\
Evapotranspiration \\
Models, \\
Meteorological \\
parameters, \\
Reference \\
evapotranspiration
\end{tabular}

Keywords

Evapotranspiration

Models,

parameters,

Reference

Article Info

Accepted:

Available Online:

10 September 2017
Agricultural planning relying on evapotranspiration suffers due to inaccuracy in its estimation. The non-availability of meteorological parameters required for accurate estimation of reference evapotranspiration (ETo) resulted in the development of different methods of ETo estimation. The present study compares various universally accepted methods of ETo estimation by considering the Penman Monteith (FAO 56 PENMEN-MONTEITH) as a standard method. Among All the five models when compared with FAO Pen-Men Method, Makkins Model was found to be the best model with $\mathrm{R}^{2} 97$ percent and Ivanos model as least performance model with $\mathrm{R}^{2} 86$ percent for the present location. It was found that reference evapotranspiration was higher in June -July and least in DecemberJanuary. Among 15 years, average evapotranspiration was higher in 2007 (2.65 $\mathrm{mm} /$ day $)$ and least in $2014(2.32 \mathrm{~mm} /$ day.

\section{Introduction}

Evapotranspiration may be defined as the sum of evaporation rate from soil surface and the amount of water absorbed by plant roots and transpired from the surface of branches and leaves. There are almost fifty methods for estimating evapotranspiration; however, the methods present different results due to their various hypotheses and input data requirements in different climatic regions (Grismer, 2002). A large number of models were developed to estimate $\mathrm{ET}_{\mathrm{O}}$ for use in environments that lack direct ETo measurements (Pereira and Pruitt 2004, Gavilain et al., 2006). Although the combination based Penman-Monteith (P-M) equation is considered the best method (Allen et al., 1998) across a wide range of climates and is recommended by the FAO as the standard method. (Referred to as FAO-56 P$\mathrm{M})$, there is evidence that other methods performed better for certain climates (AlGhobari, 2000, De Bruin and Stricker, 2000 and Lascano and van Bavel, 2007). Therefore, to reduce the uncertainty associated with the 
$\mathrm{ET}_{\mathrm{O}}$ method Selected a systematic evaluation is needed to verify its accuracy for the local climate. The reference evapotranspiration is defined as the $E T$ rate from a uniform surface of dense, actively growing vegetation having specified height and surface resistance, not short of soil water, and representing an expanse of at least $100 \mathrm{~m}$ of the same or similar vegetations (Allen et al., 2005). The concept of the ETo was introduced to study the evaporative demand of the atmosphere independent of crop type, crop development, and management practices. If water is abundantly available at the reference surface, soil factors do not affect $E T$; however, ET may decrease overtime as soil water content decreases. Accurate evapotranspiration estimates are needed to determine the water requirement of crops for irrigation scheduling. Field measurement of evapotranspiration is rarely available and actual crop evapotranspiration $\left(\mathrm{ET}_{\mathrm{c}}\right)$ is usually determined from reference crop evapotranspiration $\left(\mathrm{ET}_{\mathrm{o}}\right)$ using the crop factor method, which consists of multiplying $\mathrm{ET}_{\mathrm{o}}$ with crop specific coefficients $\left(\mathrm{K}_{\mathrm{c}}\right)$ to obtain $\mathrm{ET}_{\mathrm{c}}$ (i.e., $\mathrm{ET}_{\mathrm{c}}=\mathrm{ET}_{\mathrm{o}} \times \mathrm{K}_{\mathrm{c}}$ ). The field based direct measurement of ETo by using Lysimetric method, though very much accurate, cannot be used everywhere because of high cost involved in installation and maintenance of lysimeter. Therefore computation of reference evapotranspiration with available meteorological data is one of the important tasks for irrigation planners, researchers to design storage reservoir, which can give the maximum benefit.

\section{Materials and Methods}

\section{Site and climate}

The study was conducted on a maize crop (Zea mays) at SKUAST-Kashmir, Shalimar Research Farm, located at $34.5^{\circ} \mathrm{N}$ latitude and $74.8^{\circ} \mathrm{E}$ longitude and $1583 \mathrm{~m}$ above mean sea level. The meteorological data on temperature, humidity, rainfall, sunshine, wind speed, etc. was collected from the Division of Agronomy, SKUAST-K. Other data was calculated from the empirical formulas given in the FAO-56 manual. The (average) daily net radiation expressed in mega joules per square metre per day (MJ $/ \mathrm{m} / 2$ day) is required. These data are not commonly available but can be derived from the (average) shortwave radiation measured with a pyrometer or from the (average) daily actual duration of bright sunshine (hours per day) measured with a (Campbell-Stokes) sunshine recorder. The (average) daily wind speed in metres per second $(\mathrm{m} / \mathrm{s})$ measured at $2 \mathrm{~m}$ above the ground level is required.

\section{Estimation of reference crop evapotranspiration with different models}

The evapotranspiration from a reference surface is called the reference crop evapotranspiration and is denoted by $\mathrm{ET}_{\mathrm{o}}$. The reference surface is a hypothetical grass reference crop with an assumed crop height of $0.12 \mathrm{~m}$, a fixed surface resistance of $70 \mathrm{sm}^{-1}$ and an albedo of 0.23 . The concept of $\mathrm{ET}_{\mathrm{o}}$ was introduced to study the evaporative demand of the atmosphere independently of crop type, crop development stage and management practices. The only factors affecting $\mathrm{ET}_{\mathrm{o}}$ are climatic parameters. As a result, $\mathrm{ET}_{\mathrm{o}}$ is a climatic parameter and can be computed from weather data.

$\mathrm{ET}_{\mathrm{o}}$ expresses the evaporative demand of the atmosphere at a specific location and time of the year and does not consider crop and soil factors. The reference $\mathrm{ET}_{\mathrm{o}}$ was computed using daily values of the climatic parameters obtained from the meteorological station of the Division of Agronomy, SKUAST-K from April, 2001- June, 2015. Five different models were used to calculate the reference evapotranspiration for the year 2015. The 
FAO Penman-Monteith method is used to estimate $\mathrm{ET}_{0}$. The equation is:

$\mathrm{ET}_{0}=\frac{0.408 \Delta\left(\mathrm{R}_{\mathrm{n}}-\mathrm{G}\right)+\gamma \frac{900}{\mathrm{~T}+273} \mathrm{u}_{2}\left(\mathrm{e}_{\mathrm{s}}-\mathrm{e}_{\mathrm{a}}\right)}{\Delta+\gamma\left(1+0.34 \mathrm{u}_{2}\right)}$

\section{Priestley-Taylor model}

The equation developed by Priestley-Taylor to estimate evapotranspiration is a simplification of the FAO Penman-Monteith equation, where the aerodynamic part is neglected. Since the relative importance of the aerodynamic part of the FAO PenmanMonteith equation is high during night and winter, the Priestley-Taylor underestimates evapotranspiration during those periods.

$E T_{\circ}=\alpha \cdot \frac{\Delta}{\Delta+y} \cdot \frac{R_{n}}{\lambda}$

\section{Hargreaves model}

The model to estimate ET after Hargreaves is a strongly empirical model. Both, radiation and temperature are used as input data. Its main advantage is that no radiation has to be measured, since the model works with calculated extraterrestrial radiation.

$E T_{0}=0.0023 R_{a} T D^{\frac{1}{2}}(T+17.8)$

\section{Makkins model}

$E T_{\circ}=0.61 \cdot \frac{\Delta}{\Delta+y} \cdot \frac{R s}{\lambda}-0.12$

\section{Blaney-Criddle model}

$$
E T=\{a+b[P(.46 T+8.13)]
$$

\section{Ivanov model}

A modified formula after Ivanov is widely used to estimate monthly evapotranspiration for the winter months i.e. November till February. The equation is:
$E T_{0}=0.000036(25+T)^{2} \cdot(100-R H)(6)$

\section{Results and Discussion}

\section{Reference evapotranspiration $\left(\mathbf{E T}_{0}\right)$}

The study shows a considerable variation in the reference evapotranspiration over a period of 15 years, irrespective of soil type and crop type, as it largely depends on climatic condition rather than soil and crop properties. The estimated change in reference evapotranspiration calculated using FAO-56 modified Penman Montieth approach over a period of 15 is years is shown in table 3.1 and illustrated in fig.3.1.It is evident from the figure that maximum evapotranspiration occurs during the months of June-July and minimum evapotranspiration occurs during the months of December-January. Out of these 15 years, maximum value of ETo for any month was of $4.95 \mathrm{~mm} /$ day in June 2011 and minimum was $0.63 \mathrm{~mm} /$ day in January 2006 and in January 2014.

Also Among 15 years, Avg. Evapotranspiration was higher in 2007(2.65 $\mathrm{mm} /$ day $)$ and least in 2014(2.32 mm/day).The difference in ETo is attributed to combined effects of temperature, sunshine hours, radiation, wind, wind speed and humidity.

\section{Performance evaluation of ET Estimation methods}

The regressions analysis was done to examine the performance of each of five different Models compared with the standard reference Model (FAO-56 PM Model). The comparative evaluation of Models was performed using regression analysis $\left(\mathrm{R}^{2}\right)$ and error analysis (RMSE, MBE).The comparative evaluation performed can be used as guideline for selection of alternative or less data dependent methods in case of non-availability of data. The monthly mean $\mathrm{ET}_{0}$ values estimated by each of the six 
methods for the year 2015 used in present study are shown in Fig. 3.2.Results obtained from the regression of $\mathrm{ET}_{\mathrm{o}}$ estimated by each of the five different Models against standard
$\mathrm{ET}_{\mathrm{o}}$ (derived using FAO-PM method) are presented in Table 3.3 The best method is the one with the smallest RMSE, and the highest Coefficients of determination $\mathrm{R}^{2}$.

Table.1 Average Standard Reference Evapotranspiration ( $\mathrm{ET}_{\mathrm{o}}$ ) in mm/day from 2001-2015

\begin{tabular}{|l|l|l|l|l|l|l|l|l|l|l|l|l|l|l|l|}
\hline \multicolumn{10}{|c|}{ Years } \\
\hline MONTHS & 2001 & 2002 & 2003 & 2004 & 2005 & 2006 & 2007 & 2008 & 2009 & 2010 & 2011 & 2012 & 2013 & 2014 & 2015 \\
\hline January & 0.76 & 0.69 & 0.65 & 0.7 & 0.75 & 0.63 & 0.95 & 0.68 & 0.84 & 0.97 & 0.78 & 0.66 & 0.86 & 0.63 & 0.76 \\
\hline February & 1.06 & 1.13 & 0.98 & 1.03 & 0.87 & 1.24 & 1.23 & 1.2 & 1.34 & 1.16 & 1.08 & 1.16 & 1.19 & 1.19 & 1.2 \\
\hline March & 1.72 & 2.02 & 2.09 & 1.7 & 1.77 & 1.96 & 2.05 & 2.58 & 2.07 & 2.15 & 2.31 & 2.15 & 2.24 & 1.51 & 2.25 \\
\hline April & 2.93 & 2.81 & 3.11 & 3.05 & 3.07 & 3.24 & 3.77 & 2.92 & 3.01 & 2.77 & 2.74 & 2.77 & 2.71 & 2.52 & 2.86 \\
\hline May & 3.9 & 3.71 & 4.07 & 3.65 & 3.14 & 4.42 & 3.82 & 3.91 & 4.02 & 3.6 & 4.39 & 3.6 & 3.69 & 3.21 & 3.7 \\
\hline June & 4.27 & 4.42 & 4.47 & 4.33 & 4.53 & 4.32 & 4.36 & 4.47 & 4.32 & 4.21 & 4.95 & 4.21 & 4.58 & 4.5 & 4.3 \\
\hline July & 4.46 & 4.51 & 4.38 & 3.99 & 4.2 & 4.56 & 4.41 & 4.3 & 4.53 & 4.4 & 4.2 & 4.4 & 4.61 & 4.23 & 4.42 \\
\hline August & 4.03 & 3.74 & 3.53 & 4.21 & 4.25 & 3.63 & 3.98 & 3.88 & 4.5 & 3.61 & 3.89 & 3.61 & 3.52 & 3.81 & 3.64 \\
\hline September & 2.76 & 3.33 & 3.19 & 3.26 & 3.36 & 2.92 & 2.99 & 3.1 & 3.41 & 2.8 & 3.09 & 2.8 & 3.08 & 2.77 & 2.9 \\
\hline October & 1.99 & 1.92 & 2.03 & 2.09 & 2.1 & 2.04 & 2.27 & 2.05 & 2.16 & 1.89 & 2.05 & 1.89 & 2.08 & 1.92 & 2.03 \\
\hline November & 1.07 & 1.09 & 1.13 & 1.02 & 1.22 & 1.09 & 1.22 & 1.22 & 1.16 & 1.17 & 1.07 & 1.17 & 1 & 0.95 & 1.12 \\
\hline December & 0.73 & 0.71 & 0.77 & 0.69 & 0.74 & 0.67 & 0.73 & 0.78 & 0.8 & 0.7 & 0.75 & 0.7 & 0.7 & 0.7 & 0.76 \\
\hline Average & $\mathbf{2 . 4 7}$ & $\mathbf{2 . 4 5}$ & $\mathbf{2 . 5 3}$ & $\mathbf{2 . 4 7}$ & $\mathbf{2 . 5}$ & $\mathbf{2 . 5 6}$ & $\mathbf{2 . 6 5}$ & $\mathbf{2 . 5 9}$ & $\mathbf{2 . 6 7}$ & $\mathbf{2 . 4 5}$ & $\mathbf{2 . 6 0}$ & $\mathbf{2 . 4 2}$ & $\mathbf{2 . 5 2}$ & $\mathbf{2 . 3 2}$ & $\mathbf{2 . 4 9}$ \\
\hline
\end{tabular}

Table.2 Avg. Reference Evapotranspiration $\left(\mathrm{ET}_{\mathrm{o}}\right)$ in $\mathrm{mm} /$ day for the year 2015 calculated with different models

\begin{tabular}{|c|c|c|c|c|c|c|}
\hline Months & FAO-56 PM & BLANEY-CRIDDLE & HARGREAVES & MAKKINS & PRIESTLY-TAYLOR & IVANOV \\
\hline JAN & 0.76 & 1.925 & 2.131 & 0.763 & 0.925 & 0.763 \\
\hline FEB & 1.2 & 2.176 & 2.197 & 0.991 & 1.042 & 0.865 \\
\hline MAR & 2.25 & 3.162 & 2.821 & 1.765 & 2.114 & 0.873 \\
\hline APR & 2.86 & 3.633 & 6.328 & 1.985 & 2.731 & 1.574 \\
\hline MAY & 3.7 & 4.218 & 9.182 & 2.861 & 3.661 & 1.942 \\
\hline JUN & 4.3 & 5.365 & 10.671 & 2.932 & 4.153 & 2.883 \\
\hline JUL & 4.42 & 6.091 & 11.603 & 2.904 & 4.245 & 3.013 \\
\hline AUG & 3.64 & 5.923 & 10.043 & 2.712 & 4.021 & 2.791 \\
\hline SEP & 2.9 & 5.109 & 8.143 & 2.318 & 3.298 & 1.551 \\
\hline OCT & 2.03 & 4.534 & 6.209 & 1.533 & 2.378 & 1.108 \\
\hline NOV & 1.12 & 3.867 & 4.512 & 1.221 & 1.462 & 0.873 \\
\hline DEC & 0.76 & 2.329 & 3.023 & 0.856 & & 1.287 \\
\hline
\end{tabular}

Table.3 Summary statistics of regression and error (mm/day) analysis between Standard and estimated $\mathrm{ET}_{\mathrm{o}}$

\begin{tabular}{|c|c|c|c|c|c|c|}
\hline Method & $\mathbf{R}^{\mathbf{2}}$ & RMSE & MBE & Intercept & Slope & F-test \\
\hline Makkinks & 0.97 & 0.49 & -0.59 & -0.53 & 1.59 & 375 \\
\hline Priestly-Taylor & 0.96 & 0.53 & 0.11 & -0.25 & 1.05 & 253 \\
\hline Hargreaves & 0.87 & 3.2 & 3.91 & 0.17 & 0.36 & 71.8 \\
\hline Ivanov & 0.86 & 0.67 & -0.9 & 0.22 & 1.43 & 62.5 \\
\hline Blaney-Criddle & 0.73 & 1.46 & 1.53 & -0.73 & 0.8 & 28.1 \\
\hline
\end{tabular}


Fig.1 Mean Standard Evapotranspiration of 15 years

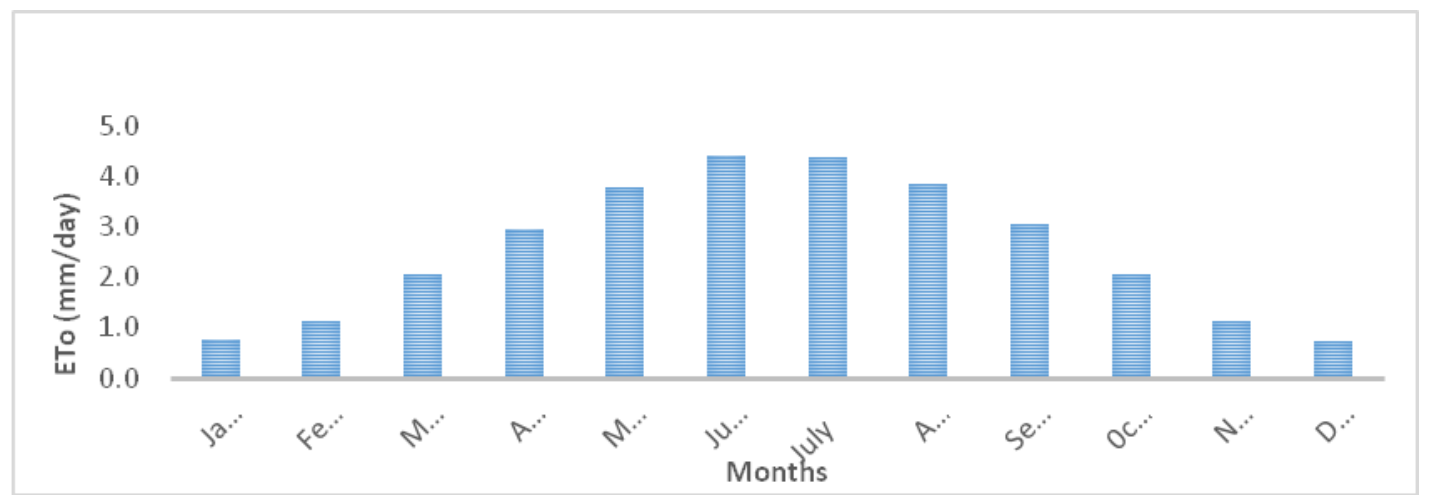

Fig.2 Comparison of Standard (FAO-56) and estimated mean monthly ET0 (mm/day) for the year 2015

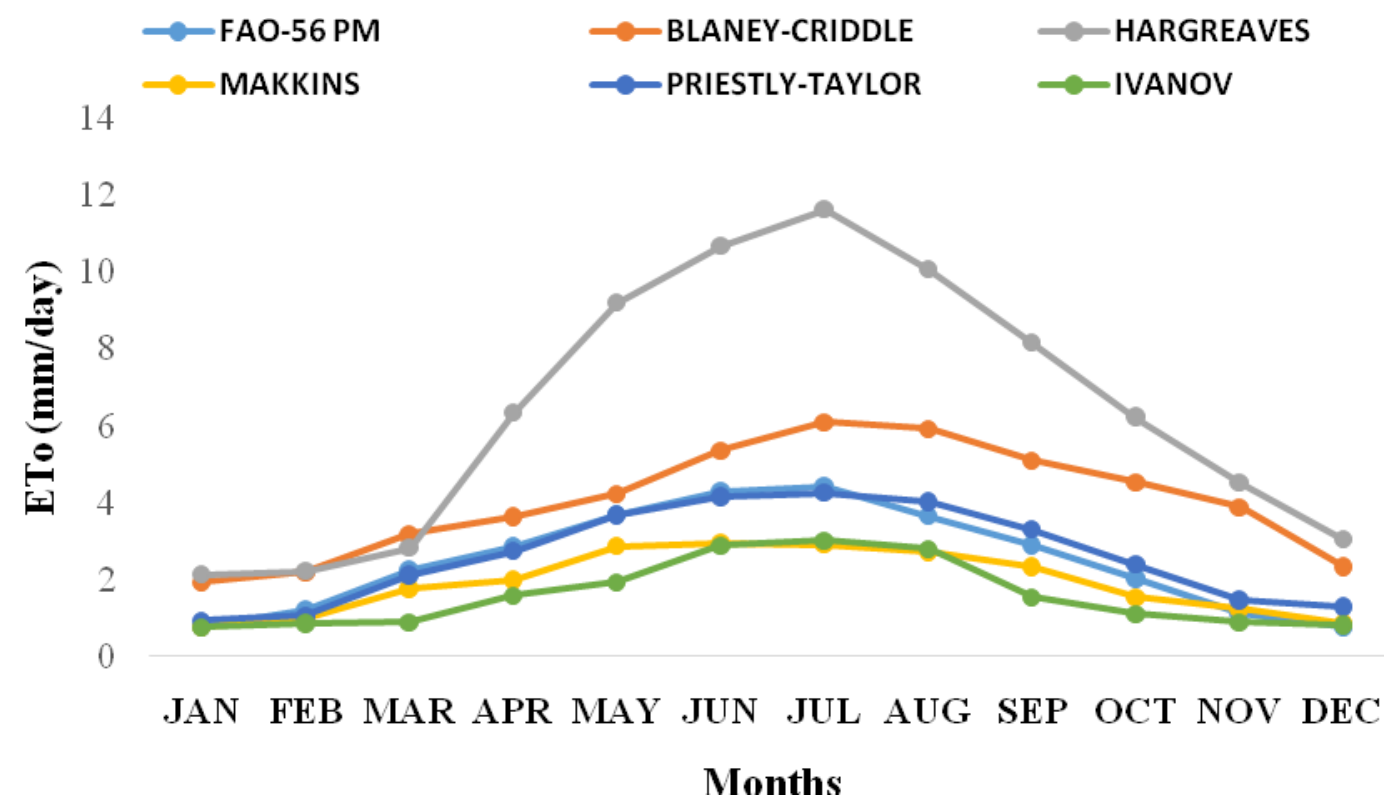

The comparative evaluation of error and regression analysis results as illustrated from Table 4.4 and Fig.3.2 indicates that the Makkinks method performed best with the lowest RMSE 0.49 and highest $\mathrm{R}^{2}$ 0.97.The results of Priestley-Taylor model has shown second best performance $\left(\mathrm{R}^{2}=0.96\right.$, RMSE $=$ $0.53 \mathrm{~mm} /$ day and MBE: $0.11 \mathrm{~mm} /$ day) among the other methods. Blaney-Criddle equation is least suitable method for estimation of evapotranspiration for present location due to lowest $\mathrm{R}^{2}$ of 0.73 and highest RMSE of 1.46 $\mathrm{mm} /$ day. The value of $F$ test revealed that in all the select methods the values were significant at 5\% level of significance. Makkinks method gives the best result for Ftest with highest value of 375 compared to other methods.

In conclusion, Regression equations between ETo estimated through Penman Monteith method and other methods indicated that the 
most significant method of computing ETo is Makkinks method $\left(\mathrm{R}^{2}=97 \%\right)$ which requires only radiation and temperature data. Priestley and Taylor $\left(\mathrm{R}^{2}=96 \%\right)$ is apparently the second best method to obtain reliable $\mathrm{ET}_{\mathrm{o}}$ value followed by Hargraves method $\left(\mathrm{R}^{2}=87 \%\right)$ and Ivanov method $\left(\mathrm{R}^{2}=86 \%\right)$ respectively. Blanney-Criddle method $\left(\mathrm{R}^{2}=73 \%\right)$ produced substantially lower $\mathrm{R}^{2}$ values. The study demonstrated the usefulness of statistical techniques for validating the reference evapotranspiration values obtained by using different ETo estimation methods. The inaccuracies in ETo estimations are a major hindrance in developing effective water management strategies for maintaining crop water requirement during drought periods.

\section{References}

Al-Ghobari, H.M., 2000. Estimation of reference evapotranspiration for southern region of Saudi Arabia, Irrig. Sci. 19 (2) (2000), 81-86.

Allen, R.G., Pereira, L.S., Raes, D., Smith, M., 1998. Crop evapotranspiration Guidelines for computing crop water requirements - FAO Irrigation and drainage paper 56. Food and agriculture Organization of the United Nations, Rome.

Allen, R.G., Smith, M., Pereira, L. S. and Perrier, A.: 1994, 'An Update for the Calculation of Reference Evaporation', ICID Bull. 43, 35-92

Blaney, H. F., and Criddle W. D. 1950. Determining water requirements in irrigated area from climatologically irrigation data. US Department of Agriculture, Soil Conservation Service, Tech. Paper No. 96.

De Bruin, H.A.R., and Stricker, J.N.M. 2000. Evaporation of grass under nonrestricted soil moisture conditions, Hydro. Sci. J. 45 (3), 391-406

Garcia, M., Raes, D., Allen, R. G., \& Herbas,
C. 2006. Dynamics of reference evapotranspiration in the Bolivian highlands (Altiplano). Agriculture and Forest Meterology, 125, 67-82.

Gavilán, P., Lorite, I. J., Tornero, S. and Berengena, J. 2006. Regional calibration of HAG equation for estimating reference ET in a semiarid environment. Agricultural Water Management, 81, 257-281 Evapotranspiration Conversion Methods. Journal of Irrigation and Drainage Engineering, 128(3), 180184.

Grismer, M. E., Orang, M., Snyder, R. \& Matyac, R. 2002. Pan Evaporation to Reference.

Hargreaves, G. H., \& Allen, R. G. 2003. History and Evaluation of Hargreaves Evapotranspiration Equation. Journal of Irrigation and Drainage Engineering, 129 (1), 53-63.

Hargreaves, G. H., and Z. A. Samani. 1985. Reference crop evapotranspiration from temperature, Transaction of the ASAE 28 (1): 96-99.

Hargreaves, G. L., \& Samani, Z. A. 1982. Estimating potential evapotranspiration. Journal of Irrigation and Drainage Engineering, 108 (2), 225-230.

Lascano and Bavel V. 2007. R.J. Lascano and C.H.M. van Bavel, Explicit and recursive calculation of potential and actual evapotranspiration, Apron. J. 99, 585-590.

Makkink, G. F., 1957. Testing the Penman formula by means of Lysimeters', $J$. Inst. Water Engineers 11: 277-288

Nandagiri, L. and Kovoor, G. M. 2006. Performance Evaluation of Reference Evapotranspiration Equations across a Range of Indian Climate." ASCE Journal of Irrigation and Drainage Engineering, Vol. 132 (3).

Parmele, L. H. and McGuinness, J. L. 1974. Comparisons of measured and estimated 
daily potential evapotranspiration in a humid region. Journal of Hydrology, 22, 239-251.

Penman, H. L., 1948. Natural evaporation from open water, bare soil and grass. Proc., Royal Soc., London, 193: 120 145

Priestley, C. H. B., and Taylor, R. J. 1972. On the assessment of the surface heat flux and evaporation using large-scale parameters. Monthly Weather Review
100: 81-92

Pruitt, W. O., and Aston, M. J.: 1963, 'Atmospheric and Surface Factors Affecting Evapotranspiration', Final Report to USAEPG on Contract No. DA-36-039.SC-80334, Univ. of California-Davis, pp. 69-105.

Xu, C.Y., and Singh, V. P. 2000. Evaluation and generalisation of radiation-based equations for calculating evaporation. Hydrological Processes 14, 339-397

\section{How to cite this article:}

Shakeel Ahmad Bhat, Bashir Pandit, Mehraj U. Din Dar, Rehana Jan, Shafat Khan and Khanday Mehraj. 2017. Statistical Comparison of Reference Evapotranspiration Methods: A Case Study from Srinagar in J\&K. Int.J.Curr.Microbiol.App.Sci. 6(9): 3731-3737. doi: https://doi.org/10.20546/ijcmas.2017.609.460 